\title{
VEGETATIVE GROWTH AND YIELD OF ROBUSTA COFFEE GENOTYPES CULTIVATED UNDER DIFFERENT SHADING LEVELS
}

\author{
CRESCIMENTO VEGETATIVO E PRODUÇÃO DE GENÓTIPOS DE CAFÉ \\ ROBUSTA CULTIVADOS SOB DIFERENTES NÍVEIS DE SOMBRA
}

\author{
Luan Peroni VENANCIO ${ }^{1}$; José Francisco Teixeira do AMARAL ${ }^{2}$; Paulo Cezar CAVATTE $^{3}$; \\ Cynthia Teixeira VARGAS ${ }^{3}$; Edvaldo Fialho dos REIS ${ }^{3}$; Jocione Ribeiro DIAS ${ }^{3}$ \\ 1. Federal University of Viçosa, Agricultural Engineering Department, Viçosa, MG, Brazil. \\ luan.venancio@ufv.br; 2. Federal University of Espírito Santo, Rural Engineering, Alegre, ES, Brazil; \\ 3. Federal University of Espírito Santo, Biology Department, Alegre, ES, Brazil
}

\begin{abstract}
The growing in shaded systems is one of the strategies adopted to mitigate the impacts of climate change on coffee trees. However, there are few studies about the effect of shading on the growth and production of clones of robusta coffee (Coffea canephora). Besides that, exist a paradigm in Brazil of that the shading in coffee robusta is synonymous of less yield. Thus, the aim of this work was to evaluate whether $C$. canephora genotypes subjected to shading increase their yield and growth vegetative under field conditions. The study was performed between September 2013 and July 2017 (four harvests) in Alegre, Espírito Santo state, Brazil. Three genotypes of cultivar Conilon Vitória - Incaper 8142 were evaluated $(03 \mathrm{~V}, 06 \mathrm{~V}$, and $12 \mathrm{~V})$ and four levels of shade: full sunlight (witness) and, low, moderate and, high shade, with 38, 48 and, 68\% of real capacity of shade, respectively. The shade was performed using black polyolefin screens; plants growing in full sunlight were only fenced. The tested shade levels affected the growth rate and yield of Robusta coffee plants. The shading caused a greater leaf expansion as compared to the full sunlight, as well as greater etiolation of the plagiotropic and orthotropic branches. The genotype 06V was shown to be responsive to shading, with a statistically equal production independently of shade level. The low, moderate, and high shade levels affected negatively the yield of genotypes $03 \mathrm{~V}$ and $12 \mathrm{~V}$. The shading can improve the yield of Robusta coffee, in this case, of the genotype 06V of the cultivar Conilon Vitória - Incaper 8142. The success of shaded plantations depends the choice of the shade responsive genotypes and appropriate shading level.
\end{abstract}

KEYWORDS: Coffea canephora. Light intensity. Shaded Coffee. Productivity.

\section{INTRODUCTION}

In Coffea genus, only C. arabica (arabica coffee) and C. canephora (robusta coffee) are economically important worldwide. These species have been cultivated in open fields in many tropical countries worldwide despite their origin in shaded habitats (DaMATTA, 2004). In the main Brazilian area producing robusta coffee (Espírito Santo state), there is an increasing trend in expanding cultivation towards marginal and degraded lands where water availability constitutes one of the major problems. Since 2007, the Espírito Santo state has produced more than 7.3 million processed coffee bags annually, except for 2016, when production was only 5.4 million bags, a $31 \%$ drop relative to the 2015 harvest (CONAB, 2017). This decline results from drought, high temperatures and insolation and, poor rainfall distribution (CONAB, 2018). these climatic problems could be mitigated by crop shading, however, nearly a hundred percent of coffee plantations are cultivated under full sunlight.
Shaded cultivation systems are a promising agricultural alternative that promotes biodiversity conservation and subsistence of local people (BEENHOUWER et al., 2013; VALENCIA et al., 2014) while mitigating the variability in the local climate, which is the main factor influencing coffee production in Brazil (DaMATTA et al., 2018). Some of the main microclimatic changes due to shading are reduction of air and soil temperature extremes (LIN, 2007), increased soil moisture content (MORAIS et al., 2006), decreased wind speed (PEZZOPANE et al., 2011), and reduces leaf temperature (SILES et al., 2010; OLIOSI et al., 2016). Shading in coffee plants besides alter the microclimate, can cause alterations in vegetative growth and yield.

Regarding to effects of shade on vegetative growth and yield of coffee plants, studies have reported that shade causes an increased leaf area (RODRÍGUEZ-LÓPEZ et al., 2013), decreases in branch emission (MORAIS et al., 2006), increases in the internode distance (ANIM-KWAPONG et al., 
2010), and etiolation of the plagiotropic and orthotropic branches (ARAÚJO et al., 2016). About the production of Coffea canephora under shading, few studies were performed in field conditions, even that exist a demand for this information, leaving a gap of uncertainties to the coffee producer that pretends to have a coffee plantation shaded. The many information that is available in the literature it's to the yield is focused on arabica coffee. Thus, the aim of this work was to evaluate whether $C$. canephora genotypes subjected to shading increase their yield and growth vegetative under field conditions.

\section{MATERIAL AND METHODS}

\section{Experimental area and experimental design}

The study was performed between September 2013 and July 2017 with three genotypes cultivar Conilon Vitória - Incaper 8142. The plantation is located in the experimental area of the Center for Agricultural Sciences and Engineering (CCAE) of the Federal University of Espírito Santo (UFES) in Alegre, ES, Brazil $\left(20^{\circ} 45^{\prime} 48^{\prime \prime}\right.$ S; 4131'57" W; $134 \mathrm{~m}$ above sea level). This cultivar propagated by cuttings was planted in line (one genotype in each line) in March 2011, with 3.0 x 1.2 $\mathrm{m}$ spacing (2777 plants $\left.\mathrm{ha}^{-1}\right)$, following the recommendations of Capixaba Research Institute, Technical Assistance, and Rural Extension (INCAPER). The regional climate is classified how "Aw" according to the Köppen climate classification (ALVARES et al., 2013), with dry winters, hot and rainy summers, and an annual mean air temperature of approximately $23^{\circ} \mathrm{C}$.

Genotypes were selected based on their agronomical characteristics and to ensure the viability of the experiment. Previous research performed in the study region had demonstrated contrasting characteristics in the selected genotypes. Three genotypes of $C$. canephora, which are components of cultivar Conilon Vitória - Incaper 8142 were evaluated: (1) $03 \mathrm{~V}$, an intermediate maturing genotype with average yield capacity; (2) $06 \mathrm{~V}$, early maturing genotype with average yield capacity; and (3) $12 \mathrm{~V}$, an early maturing genotype with high yield capacity.

The planting in line, made it impossible to use the Randomized Complete Block Design (RCBD). Thus, the experiment was arranged in a completely randomized design (CRD), following a 4 (shade level) x 3 (genotypes) factorial scheme totaling 12 treatments and five replicates per treatment, and experimental plots containing one plant each.

\section{Plant growth conditions}

Four shade levels, full sunlight (FS) and, low shade (LS), moderate shade (MS), and high shade (HS), were established in July 2013, using black polyolefin screens with $30 \%, 50 \%$, and $70 \%$ of nominal shading capacity to the LS, MS and HS treatments, respectively; plants in full sunlight were only fenced. To check the real capacity shading of black polyolefin screens, was measured the photosynthetically active radiation (PAR; $\mu \mathrm{mol} \mathrm{s}{ }^{-1}$ $\mathrm{m}^{-2}$ ) on the coffee plants canopy for each shade level using a light meter (LI-250A, LI-COR, Lincoln, NE, USA). Was done 5 measurements during the July month of 2013 in cloudless days at midday. The measured PAR was used to calculate the real shading capacity (SC) of the screens, using the Equation 1. So, for each day was obtained a SC and, an average final of 5 measurements was performed, coming up to the following values: $0 \%$ for FS, $34 \%$ for LS, $48 \%$ for MS, and $67 \%$ for HS.

$\mathrm{SC}_{\mathrm{n}}=\frac{\mathrm{PAR}_{\mathrm{n}}}{\mathrm{PAR}_{\mathrm{PS}}}$

Where, $\mathrm{PAR}_{\mathrm{n}}$ refers to PAR measured in the black polyolefin screens with $30 \%, 50 \%$, and $70 \%$ light retention nominal capacity, respectively and, $\mathrm{PAR}_{\mathrm{FS}}$ refers to the PAR measured in full sunlight.

The light quality (blue/red and red/far red ratios) beneath the nettings as well as in the open (direct solar radiation) was checked in cloudless days at dawn, midday and dusk using a spectroradiometer (SpectraPen LM 500, PSI, CZK) following the recommendations of Smith (1982). We found alterations in the light quality in both dawn and dusk, although these alterations took place regardless of the screens that were used. Therefore, we contend that differences in the vegetative growth and yield traits in response to the light treatments that appeared in the long term were largely unrelated to light quality.

During the experiment period, were collected air temperature and rainfall were data using an automatic meteorological station, belong to National Institute of Meteorology (INMET), located near to the experimental area.

\section{Vegetative growth}

The evaluations were done always in the same branches throughout the experiment, for this, prior to the evaluations start, two orthotropic branches and four primary plagiotropic branches, which emerge from orthotropic branches, were selected on each plant, marked, and identified. The 
vegetative growth was obtained only in the season $2013 / 14$, to the three main phenological stages of Robusta coffee, that is, early fruiting, grain-filling and fruit maturation (Figure 1). For such purpose, each 20 days, non-destructive measurements were performed. The following variables were determined for each one of phenological stages: (a) mean orthotropic branch growth rate (OGR; $\mathrm{mm} \mathrm{d}^{-1}$ ) , (b) mean plagiotropic branch growth rate (PGR; $\mathrm{mm} \mathrm{d} \mathrm{d}^{-1}$ and, mean plagiotropic branch node emission rate (PER; nodes month-1). OGR and PGR were obtained by the difference between branch lengths in period $(\mathrm{mm})$ divided by the number of days in the period (20) and, PER by the difference between node number in period, divided by the number of days in the period (20). The OGR, PGR and PER final values were obtained from the average of number of measurements performed within of the phenological stage (Figure 1). The results of PER were present in nodes per month. It should be noted that the transition between phenological stages is a continuous process in coffee, so the lower and upper limits for each stage are approximations.

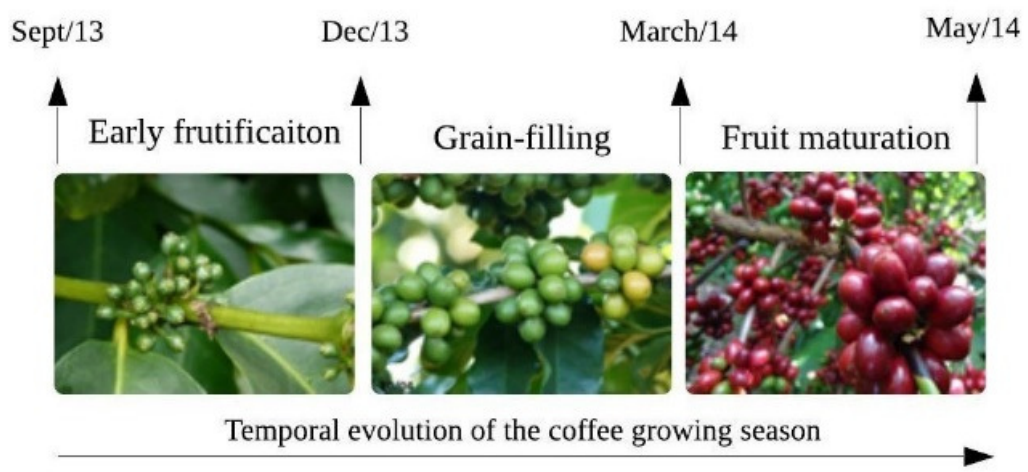

Figure 1. Average period of comprehensiveness of the three main phenological stage of Robusta coffee.

The growth vegetative also was evaluated by means of a destructive measurement (cutting previously marked plagiotropic branches), performed once in the 2014 year. The period of these measurements depended on the optimal harvest time ( $80 \%$ mature beans or more) for each genotype. The following growth variables were determined from final evaluation: (a) average plagiotropic branch internode length (PIL; cm), calculated as the ratio of the branch length to the number of nodes; (b) average orthotropic branch internode length (OIL; cm), calculated as the ratio of the orthotropic branch length to the number of plagiotropic branches; (c) leaf area per leaf (LA; $\mathrm{cm}^{2}$ ), determined by measuring the area of 20 randomly chosen intact leaves using a leaf area meter (Li-3100; LI-COR, USA) and calculating the mean area; (d) specific leaf area (SLA; $\mathrm{cm}^{2} \mathrm{~g}^{-1}$ ), which was determined by harvesting the third pair of leaves from the apex of the plagiotropic branch and collecting ten leaf disks of known area from each leaf using a cork borer. The disks were dried in a forced air circulation oven at $65{ }^{\circ} \mathrm{C}$ to a constant weight ( \pm 72 hours), and the SLA was calculated as the total leaf disk area divided by total disk dry weight; and (e) leaf area ratio (LAR, $\mathrm{m}^{2} \mathrm{~kg}^{-1}$ ), which was determined by the total leaf area of plagiotropic branch divided by their total dry mass.

\section{Productive parameters and grain yield}

The coffee yield was obtained in four harvests (2013/14, 2014/15, 2015/16 and 2016/17). Coffee yield was evaluated based on the following variables: (a) the average number of fruits per inflorescence (NFI), calculated as the average of the total number of fruits from five inflorescences spaced uniformly along the plagiotropic branch; (b) the number of inflorescences per productive plagiotropic branch (NIB), determined by counting all of the inflorescences on each branch; (c) the total fruit production per plant (TPP; $k g$ plant ${ }^{-1}$ ), determined by weighing all fruits (cherry, green, and dry) on each plant; and (d) the total fruit production per plant benefited $\left(\mathrm{TPP}_{\text {benefited }}\right.$; $\mathrm{kg}$ plant ${ }^{-}$ ${ }^{1}$ ), determined by weighing all benefited fruits (cherry, green, and dry). The variables NFI and NIB were obtained only in the season 2013/14.

\section{Data analysis}

The data obtained by the study were subjected to Shapiro-Wilks test for normality and posteriorly submitted to analysis of variance (twoway NOVA), and if significant differences were found among the treatments, Tukey's test was used to the comparison at $\mathrm{p} \leq 0.05$, using statistical software "R" version 3.4.2. 


\section{RESULTS AND DISCUSSION}

\section{Climatic data}

Figure 2 shows the of average monthly climatic conditions of air temperature and rainfall recorded for the automated weather station belong to INMET located near of the experimental area. During the December month of 2013, rainfall occurred almost reached $500 \mathrm{~mm}$, a value very out of this month's standards in the region. In November and December of 2016, is verified again high amount of rainfall, however, near to $300 \mathrm{~mm}$. In general terms, greater quantities of rainfall occurred during October-March period (wet season) and, smaller quantities in between April-September period (dry season). In relation to the air temperature, high values are were verified during the summer of 2014/15 and 2015/16, with temperatures reaching around $30^{\circ}$. In these two seasons, the drought and high temperatures affected several coffee plantations in the Espírito Santo state, causing crop high drop in production.

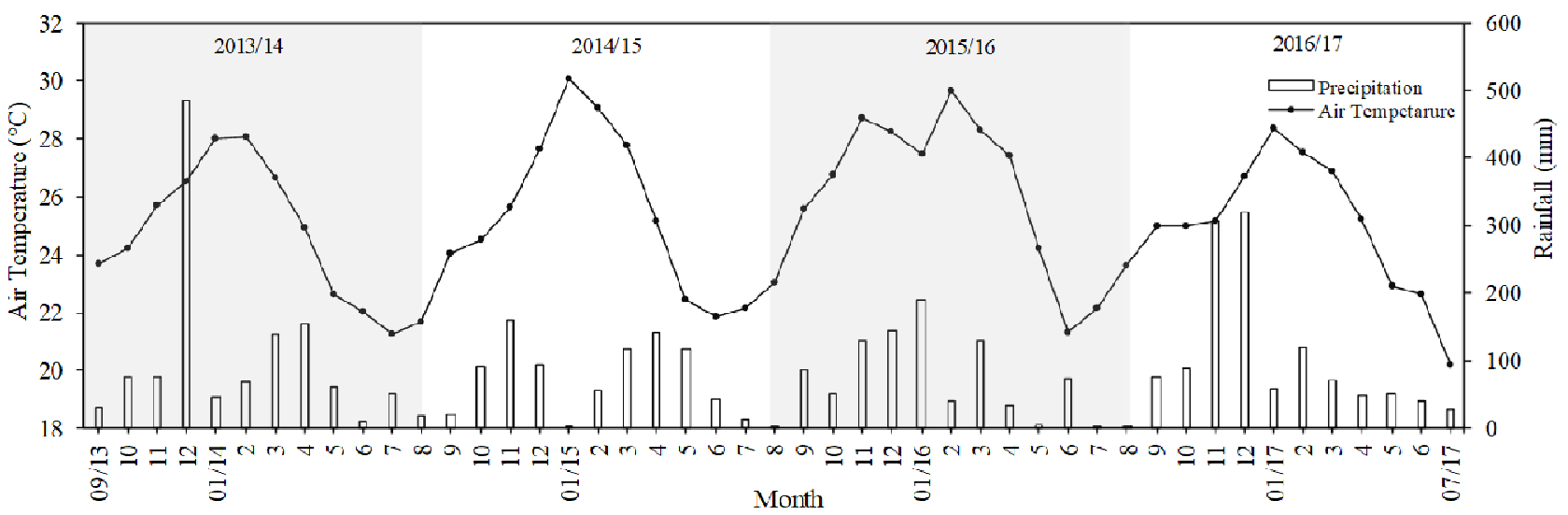

Figure 2. Mean monthly air temperature and rainfall data for the municipality of Alegre-ES during the September 2013 to July 2017 experimental period. Alegre-ES, Source: INMET.

\section{Vegetative growth}

Natural shade involves both decreases in light quantity and alterations in light quality. Here, we were able to examine effect of levels of artificial shade on the vegetative growth and yield of robusta coffee genotypes under field conditions by using black polyolefin screens nettings which have previously been demonstrated to cause no significant effect on light quality (e.g. RODRÍGUEZ-LÓPEZ et al., 2014), a fact that was further corroborated in this study. Therefore, we contend that differences in the growth traits in response to the light treatments that appeared in the long term were largely unrelated to light quality.

The studied genotypes presented similar branch growth [orthotropic (OGR) and plagiotropic (PGR)] responses when subjected to different shade levels. Independent of genotype and light availability, branch growth significantly decreased during grain-filling and resumed during fruit maturation (Figure 3A and B). A plant may be regarded as a series of sources and sinks with an overall carbon fixation capacity and several sinks "competing" for the available photo-assimilates and, this creates a priority system among sinks. During the reproductive stage, tubers, fruit, and seeds become major sinks, and may strongly restrict vegetative growth, especially during the grain-filling stage, how verified in this study (LEMOINE et al., 2013).

In respect to early fruiting stage, OGR was higher for plants grown under $\mathrm{HS}\left( \pm 5 \mathrm{~mm} \mathrm{~d}^{-1}\right)$ than under FS or MS $\left( \pm 2 \mathrm{~mm} \mathrm{~d}^{-1}\right)$ for genotypes $03 \mathrm{~V}$ and $12 \mathrm{~V}$, respectively, and it was higher for plants grown under HS and MS for genotype 06V. During the fruit maturation stage, the genotype $06 \mathrm{~V}$ was that show lower OGR in the treatments of FS, LS and MS (Figure 3A). At the early fruiting and grainfilling stages, no differences in PGR were observed among the different levels of shade in genotype $03 \mathrm{~V}$, which presented a mean PGR of $2.5 \mathrm{~mm} \mathrm{~d}^{-1}$ for the early fruiting stage and $0.6 \mathrm{~mm} \mathrm{~d}^{-1}$ for the grain-filling stage (Figure 3B).

A similar behaviour can be observed between PGR and PGR, when leads in to account the phenological stages. Durante early fruiting stage, the genotype $03 \mathrm{~V}$ presented the higher PGR, independently of the shade level. Already, the genotype $06 \mathrm{~V}$ and $12 \mathrm{~V}$ presented a low relatively value of PGR during the early fruiting stage when it grown under FS $\left( \pm 1.2 \mathrm{mmd}^{-1}\right)$; however, FS treatment in the $06 \mathrm{~V}$ did not differ significantly from the LS and MS treatments. 

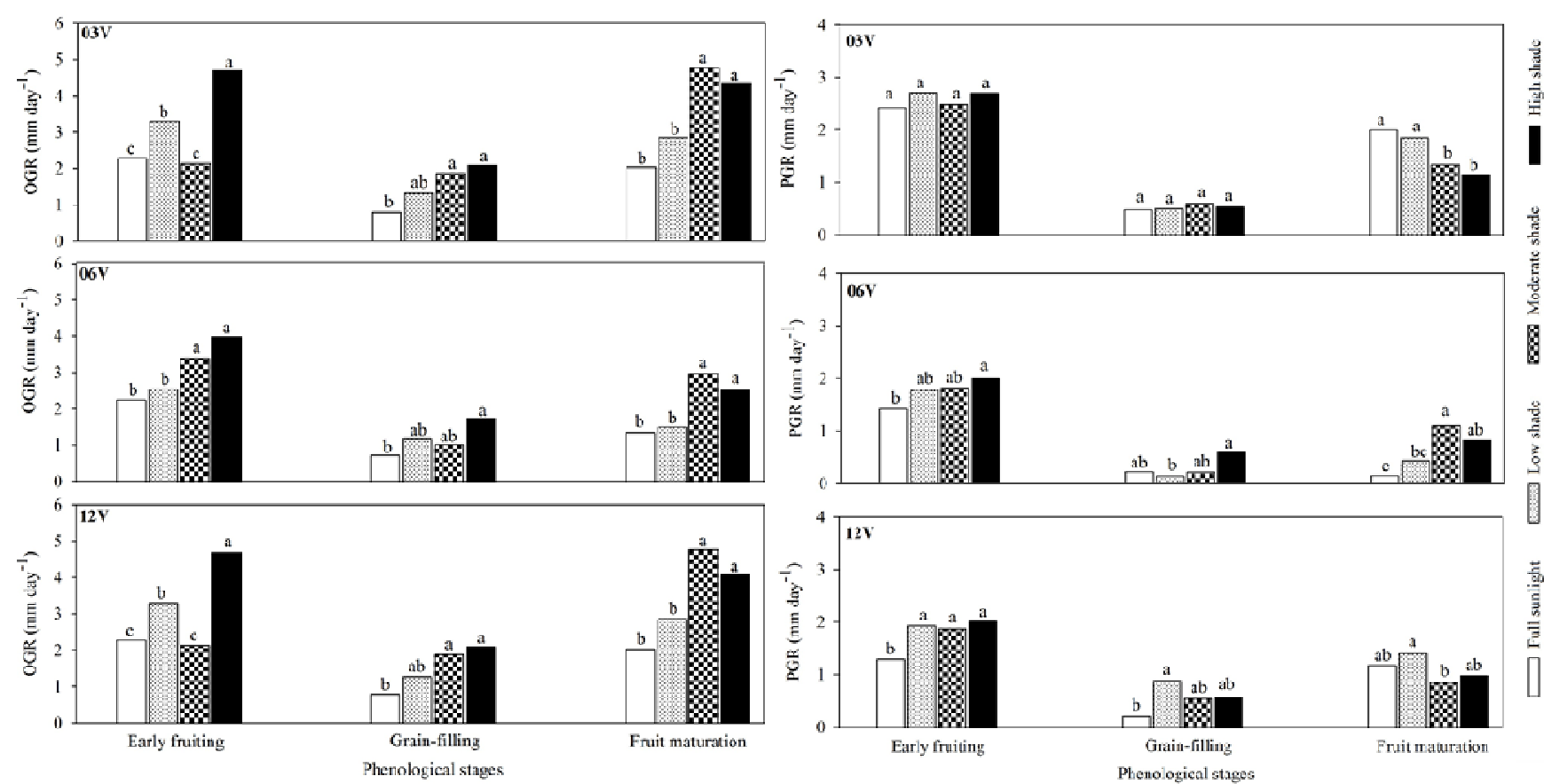

Figure 3. Mean orthotropic branch growth rate (OGR; 3A) and mean plagiotropic branch growth rate (PGR; 3B) of three Coffea canephora genotypes grown under varying levels of shade in three phenological stage. Season evaluated: 2013/2014. Means followed by the same lowercase letter for the same phenological stage and genotype, and uppercase letters within the same phenological stage, were not significantly different according to Tukey's test at $\mathrm{p} \leq 0.05$.

The grain-filling stage was characterized by slow growth, with growth rates always lower than $1.0 \mathrm{~mm} \mathrm{~d}^{-1}$ for three genotypes. Evaluating the growth of plagiotropic branches in robusta coffee, Partelli et al. (2010) observed that the growth rate varied throughout the year, how to see in this work. According with these authors, the low-growth phase seemed to be related to the minimum air temperature. Already Covre et al. (2016) evaluated the vegetative growth of robusta coffee plants, verified that growth rate of the plagiotropic branches was limited the fruit load capacity.

During the fruit maturation stage, the genotype $06 \mathrm{~V}$ was that presented the lower PGR in the treatments FS and LS (Figure 3B). Genotype $12 \mathrm{~V}$ presented a lower PGR under FS during the early fruiting and grain-filling stages. At the fruit maturation stage, differences were only observed between LS and MS. It should also be noted that the growth rates during the grain-filling stage were up to four times slower than those observed in the early fruiting stage (Figure 3A and B). Similar investigation, also with robusta coffee, observed that the proximity of the coffee tree to the rubber trees promotes the elongation of the plagiotropic and orthotropic branches (PARTELLI et al., 2014).

The PER of the three genotypes was similar under the four shade during the grain-filling stage, and the same pattern was observed for genotypes
$06 \mathrm{~V}$ and $12 \mathrm{~V}$ during the early fruiting stage. Genotype 03V presented a higher PER under FS during the early fruiting stage, although it was not significantly different from that under LS (Figure 4).

During the fruit maturation stage, genotypes $03 \mathrm{~V}$ and $12 \mathrm{~V}$ presented lower PER values under HS, but they were not significantly different from MS. In general, for genotypes $03 \mathrm{~V}$ and $12 \mathrm{~V}$, node emission decreased with increasing shading, as previously observed by Campanha et al. (2004). DaMatta \& Rodríguez-López (2007) studied sustainable coffee production in neotropical agroforestry systems and reported that the stimulus for vegetative bud emission increases and the formation of floral buds decreases with increasing shade.

The PER is a strong indicator of yield because the branch nodes are the locations of fruit development. As observed for branch growth, differences in node emission rates were observed between both different shade levels and different phenological stages. Whereas, the genotype 06V presented higher PER under MS and HS during fruit maturation stage, however, without difference between FS, LS and HS, indicating that it may be productive under shaded conditions. Oliosi et al. (2016) studying the microclimate and the development of $C$. canephora under different shading levels promoted by Australian cedar 
observed that the number of nodes per branch and they were similar among treatments.

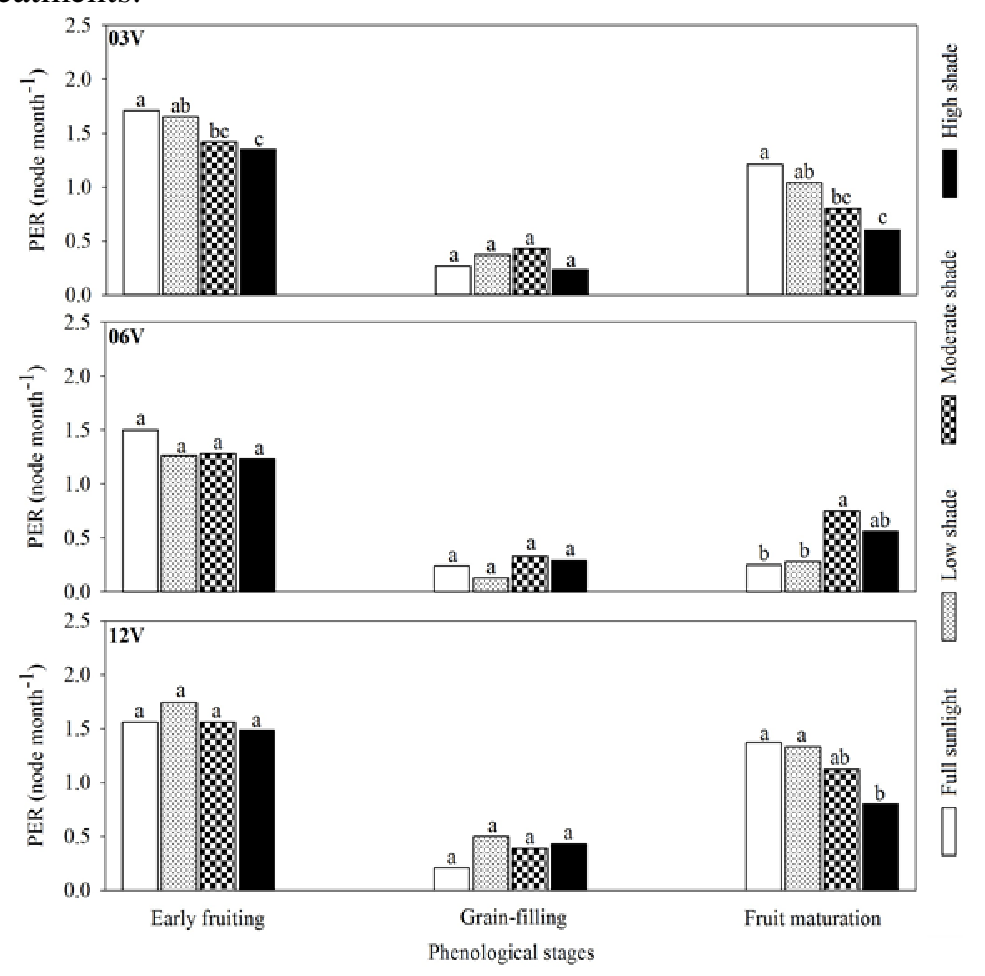

Figure 4. Mean plagiotropic branch node emission rate (PER) of three Coffea canephora genotypes grown under varying levels of shade in three phenological stage. Means followed by the same lowercase letter for the same phenological stage and genotype, and uppercase letters within the same phenological stage, were not significantly different according to Tukey's test at $p \leq 0.05$.

For all genotypes the lowest OIL was observed under FS (Table 1). The genotype 03V presented the higher OIL, independently of shade level, and the genotype $12 \mathrm{~V}$, when compared to other genotypes, presented lowest OIL in the conditions of FS and HS. (Table 1). For all genotypes the highest OIL value was observed under HS. Similar results were observed to Oliosi et al. (2016) and Partelli et al. (2014) working with Robusta coffee. The same behaviour was observed to PIL. The genotype 03V presented the higher OIL and PIL value, independently of shade level (Table $1)$.

Summarizing, independently of shade level, the higher value of PIL and OIL were observed in the following order: 03,06 and $12 \mathrm{~V}$. The OIL and PIL are very important coffee plant characteristics, because excessive increases in either may result in the formation of etiolated twigs and branches, which are more flexible and thus unable to bear the weight of the fruit.

The LA was higher for genotype $03 \mathrm{~V}$ grown under HS. But it should be noted that genotype 03V presented a higher LA than the other genotypes regardless of shade level, presenting shadow leaves even when grown under FS $\left(81.7 \mathrm{~cm}^{2}\right)$. For genotypes $06 \mathrm{~V}$ and $12 \mathrm{~V}, \mathrm{FS}$ was the least favourable condition for the development of LA (Table 1). For genotype 03V, no significant differences in SLA were observed between FS, LS, and MS or between LS, MS, and HS. Genotype 06V presented a lower SLA when grown under FS, similar result was observed to the genotype $12 \mathrm{~V}$, but without differences to LS. Occurred an increase of LAR value with shade level increase, independently of genotype. The genotype $06 \mathrm{~V}$ presented lower LA, SLA and LAR under FS, when compared to other genotypes (Table 1). 
Table 1. Mean orthotropic branch internode length (OIL), mean plagiotropic branch internode length (PIL), leaf area per leaf (LA), specific leaf area (SLA) and leaf area ratio (LAR) for different Coffea canephora genotypes grown under varying four shade level [full sunlight (FS), low shade (LS), moderate shade (MS), and high shade (HS)].

\begin{tabular}{|c|c|c|c|c|}
\hline \multirow{2}{*}{ Genotype } & \multicolumn{4}{|c|}{ Shade Level } \\
\hline & FS & LS & MS & HS \\
\hline & \multicolumn{4}{|c|}{ OIL (cm) } \\
\hline $03 \mathrm{~V}$ & $4.7 \mathrm{cA}$ & $5.9 \mathrm{bA}$ & $7.2 \mathrm{aA}$ & $7.5 \mathrm{aA}$ \\
\hline $06 \mathrm{~V}$ & $4.0 \mathrm{~dB}$ & $4.6 \mathrm{cB}$ & $5.5 \mathrm{bB}$ & $6.4 \mathrm{aB}$ \\
\hline \multirow[t]{2}{*}{$12 \mathrm{~V}$} & $3.2 \mathrm{cC}$ & $4.7 \mathrm{bB}$ & $5.2 \mathrm{abB}$ & $5.6 \mathrm{aC}$ \\
\hline & \multicolumn{4}{|c|}{ PIL $(\mathrm{cm})$} \\
\hline $03 \mathrm{~V}$ & $4.5 \mathrm{bA}$ & $5.4 \mathrm{abA}$ & $5.0 \mathrm{abA}$ & $5.9 \mathrm{aA}$ \\
\hline $06 \mathrm{~V}$ & $2.9 \mathrm{cB}$ & $4.2 \mathrm{bB}$ & $4.1 \mathrm{bB}$ & $4.9 \mathrm{aB}$ \\
\hline \multirow[t]{2}{*}{$12 \mathrm{~V}$} & $2.7 \mathrm{bB}$ & $3.2 \mathrm{bC}$ & $3.2 \mathrm{bC}$ & $4.0 \mathrm{aC}$ \\
\hline & \multicolumn{4}{|c|}{ LA $\left(\mathrm{cm}^{2}\right)$} \\
\hline $03 \mathrm{~V}$ & $81.7 \mathrm{cA}$ & $92.1 \mathrm{bA}$ & $90.4 \mathrm{bA}$ & $116.1 \mathrm{aA}$ \\
\hline $06 \mathrm{~V}$ & $41.4 \mathrm{cB}$ & $64.9 \mathrm{bB}$ & $73.1 \mathrm{abB}$ & $77.9 \mathrm{aB}$ \\
\hline \multirow[t]{2}{*}{$12 \mathrm{~V}$} & $45.5 \mathrm{bB}$ & $62.7 \mathrm{aB}$ & $65.4 \mathrm{aB}$ & $68.9 \mathrm{aC}$ \\
\hline & \multicolumn{4}{|c|}{$\operatorname{SLA}\left(\mathrm{m}^{2} \mathrm{~kg}^{-1}\right)$} \\
\hline $03 \mathrm{~V}$ & $11.5 \mathrm{bA}$ & $12.3 \mathrm{abA}$ & $13.1 \mathrm{abA}$ & $14.4 \mathrm{aA}$ \\
\hline $06 \mathrm{~V}$ & $9.2 \mathrm{~dB}$ & $11.1 \mathrm{cA}$ & $12.8 \mathrm{bA}$ & $14.7 \mathrm{aA}$ \\
\hline \multirow[t]{2}{*}{$12 \mathrm{~V}$} & $10.9 \mathrm{bA}$ & $12.3 \mathrm{abA}$ & $13.9 \mathrm{aA}$ & $13.9 \mathrm{aA}$ \\
\hline & \multicolumn{4}{|c|}{$\operatorname{LAR}\left(\mathrm{m}^{2} \mathrm{~kg}^{-1}\right)$} \\
\hline $03 \mathrm{~V}$ & $6.3 \mathrm{dA}$ & $7.4 \mathrm{cA}$ & $8.4 \mathrm{bA}$ & $10.1 \mathrm{aA}$ \\
\hline $06 \mathrm{~V}$ & $5.1 \mathrm{~dB}$ & $7.9 \mathrm{cA}$ & $8.8 \mathrm{bA}$ & $9.8 \mathrm{aA}$ \\
\hline $12 \mathrm{~V}$ & $7.2 \mathrm{cA}$ & $8.0 \mathrm{bA}$ & $9.1 \mathrm{aA}$ & $9.3 \mathrm{aA}$ \\
\hline
\end{tabular}

Means followed by the same lowercase letter within the same raw, and uppercase letters within the same column, were not significantly different according to Tukey's test at $\mathrm{p} \leq 0.05$.

Leaf area is considered one of the main plant response variables to the amount of solar radiation. In the present study, leaf area was higher under shade for the three studied genotypes, which agrees with previous reports for robusta coffee (PARTELLI et al., 2014; ARAÚJO et al., 2016; OLIOSI et al., 2016). Normally, plants respond to changing light conditions by adjusting a suite of morphological and physiological traits (LIU et al., 2016), mainly the leaf area. For shade tolerance plants, leaf area is an important feature for light capture and harvesting (WU et al., 2017), that is, the increased leaf area is a plant acclimation strategy under high shade for harvesting the greatest possible light intensity.

In the present study, thinner leaves were observed to be more frequent under lower light conditions, which is consistent with previous reports of other researchers of lower leaf thickness, higher intercellular spaces in the spongy parenchyma (MORAIS et al., 2004), and higher SLA (STEIMAN et al., 2011) in arabica coffee plants grown under shade. The increased SLA under low light is directly related to anatomical changes that may occur in shaded plants, such as a thinner cuticle, epidermis, and mesophyll; a lower proportion of palisade parenchyma, vascular, and support tissues; a higher proportion of intercellular spaces; and a lower stomatal density (BERLYN; CHO, 2000).

\section{Productive parameters and grain yield}

We evaluated two productive parameters (number of inflorescences per productive plagiotropic branch - NIB and mean number of fruits per inflorescence - NFI), and grain yield by means of measured of the total fruit production per plant (TPP) and total fruit production per plant benefited (TPP benefited). For genotypes $03 \mathrm{~V}$ and $12 \mathrm{~V}$, the lowest NIB was observed in plants grown under HS. Ronchi et al. (2016) studying the morphophysiological plasticity of plagiotropic branches in response to change in the coffee plant spacing within rows, observed that the decrease in plant spacing in the line (more shading) linearly reduced the number of fruits per branch, as a function of the reduction in the number of fruits per inflorescence. In the general, the genotype 06V presented superiors values of NIB in relation to the genotypes $03 \mathrm{~V}$ and $12 \mathrm{~V}$ (Table 2). 
Table 2. Number of inflorescences per productive plagiotropic branch (NIB) and mean number of fruits per inflorescence (NFI) for different Coffea canephora genotypes grown under varying four shade level [full sunlight (FS), low shade (LS), moderate shade (MS), and high shade (HS)].

\begin{tabular}{ccccc}
\hline \multirow{2}{*}{ Genotype } & \multicolumn{5}{c}{ Shade Level } \\
\cline { 2 - 5 } & FS & LS & MS & HS \\
\hline $03 \mathrm{~V}$ & $7.0 \mathrm{aB}$ & $6.1 \mathrm{aB}$ & $6.0 \mathrm{aB}$ & $2.6 \mathrm{bB}$ \\
$06 \mathrm{~V}$ & $9.3 \mathrm{aA}$ & $9.8 \mathrm{aA}$ & $8.7 \mathrm{aA}$ & $8.1 \mathrm{aA}$ \\
$12 \mathrm{~V}$ & $6.1 \mathrm{bB}$ & $8.7 \mathrm{aA}$ & $9.9 \mathrm{aA}$ & $2.2 \mathrm{cB}$ \\
\hline \multicolumn{5}{c}{ NIF (unit) } \\
\hline $03 \mathrm{~V}$ & $11.0 \mathrm{aA}$ & $6.1 \mathrm{bA}$ & $4.5 \mathrm{bA}$ & $4.7 \mathrm{bAB}$ \\
$06 \mathrm{~V}$ & $11.4 \mathrm{aA}$ & $7.2 \mathrm{bA}$ & $4.7 \mathrm{bA}$ & $5.6 \mathrm{bA}$ \\
$12 \mathrm{~V}$ & $9.4 \mathrm{aA}$ & $4.9 \mathrm{bA}$ & $5.0 \mathrm{bA}$ & $3.1 \mathrm{bB}$ \\
\hline
\end{tabular}

Means followed by the same lowercase letter within the same raw, and uppercase letters within the same column, were not significantly different according to Tukey's test at $\mathrm{p} \leq 0.05$.

It should be noted that NIB enables the estimation of crop yield, but it is not reliable if analysed alone because a single bean on the leaf axils of plagiotropic branches is considered an inflorescence. Therefore, the NFI was also analysed to better infer about coffee yield. In all three of the studied genotypes, the NFI was significantly higher under FS than the other shade levels, whose NFI values were not significantly different. This result demonstrates the importance of analysing NFI because a greater number of inflorescences does not always result in a higher number of fruits per branch. Without the remaining variables, a plant with the highest NIB would be estimated to have the highest yield, as in the case of LS and MS for genotype 12V (Table 2). Long et al. (2015), studied the effect of shade tree in robusta coffee production in Vietnam, and observed that there were no differences in the number of flowers per branch between shaded and unshaded coffee sites.

Genotypes $03 \mathrm{~V}$ and $12 \mathrm{~V}$ presented significantly higher TPP when grown under FS compared to the shade treatments (Figure 5). These results agree with the results of Jaramillo-Botero et al. (2010), who observed increased arabica coffee yield with increasing light availability. Haggar et al. (2011), studied shading of arabica coffee in Central America in both conventional and organic management systems and observed that the cumulative yield for the first six years was significantly higher for coffee grown under full sunlight than under shade under conventional management in Costa Rica but that the cumulative coffee yield over five years under full sunlight in Nicaragua was only significantly higher than two of the four shade levels tested. In robusta coffee, Araújo et al. (2016) verified the reduction of yield, but, only in the treatment with dense shading.
This higher coffee productivity under full sunlight may be explained by the higher degree of floral initiation under these conditions and the inability to remove fruits naturally, which, combined with the sink strength of the seed endosperm, promotes the depletion of plant reserves. This decreases branch growth, which may be detrimental to the subsequent harvest. In contrast with the other tested genotypes, genotype $06 \mathrm{~V}$ had a best performance of production under LS and MS conditions than FS, during the four harvests (Figure 5). This show that it is responsible to shade and could be interesting in breeding program for agroforestry system (AFS) adaptation. Charbonnier et al. (2017), working with light-use efficiency in coffee plants shaded, verified that although irradiance was reduced by $60 \%$ below crowns of shade trees, coffee light-use efficiency increased by $50 \%$. Based on this information, imagine that the genotype $06 \mathrm{~V}$ uses more efficiently the light than genotypes $03 \mathrm{~V}$ and $12 \mathrm{~V}$. 

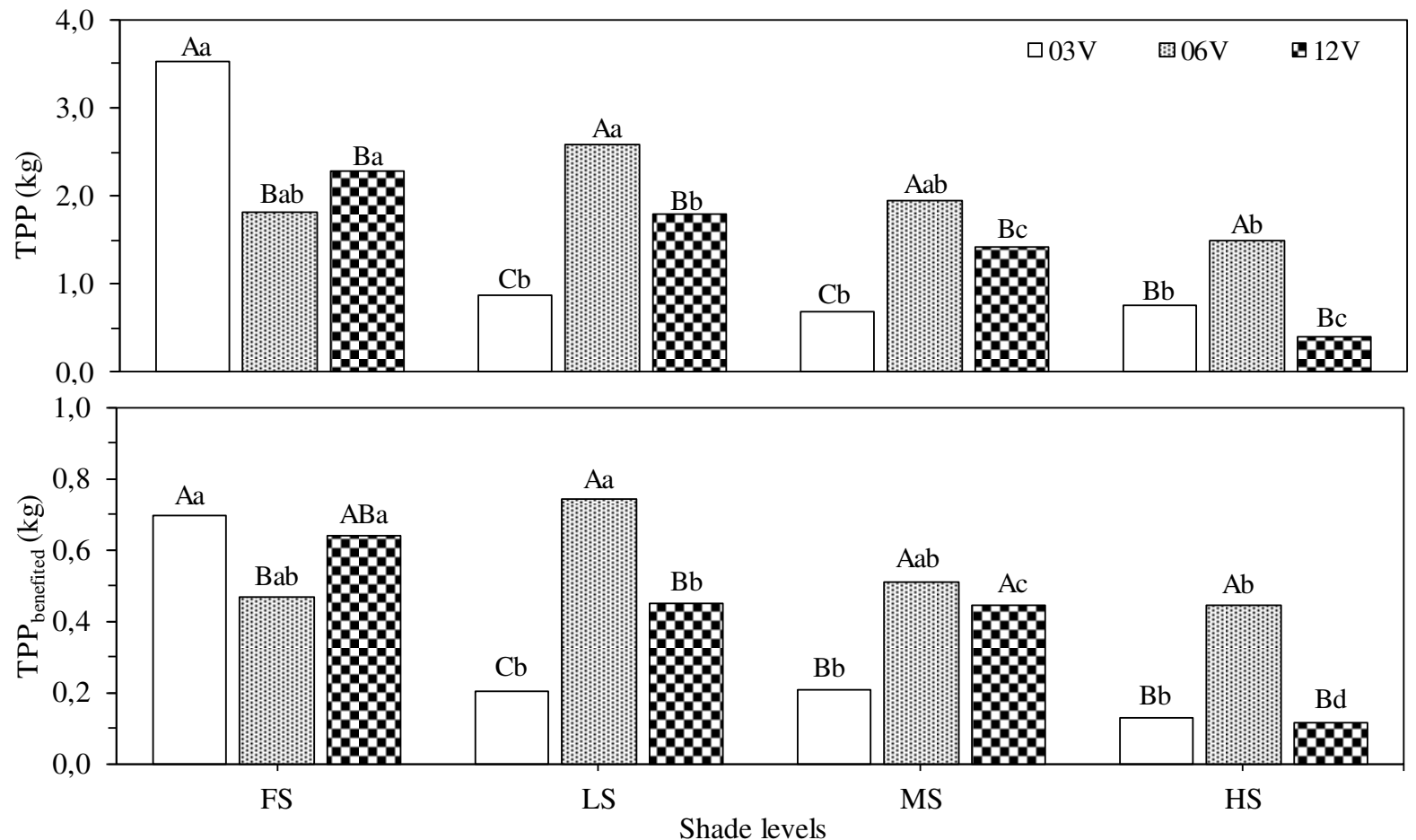

Figure 5. Total fruit production per plant (TPP) and total fruit production per plant benefited ( $\left.\mathrm{TPP}_{\text {benefited }}\right)$ of three Coffea canephora genotypes $(03 \mathrm{~V}, 06 \mathrm{~V}$ and $12 \mathrm{~V})$ grown under varying four shade level [full sunlight (FS), low shade (LS), moderate shade (MS), and high shade (HS)]. Means followed by the same lowercase letter for the same genotype, and uppercase letters within the same shade level, were not significantly different according to Tukey's test at $\mathrm{p} \leq 0.05$.

Analysing the microclimate and development of robusta coffee intercropped with rubber trees, Partelli et al. (2014) observed that shading caused by trees does not had a negative impact on grain yield. Similar results were founded by Oliosi et al. (2016) also in robusta coffee. Alves et al. (2016), working with robusta coffee production under shade and full sun in Rondônia state, Brazil, verified that shaded and full sun productivity did not differ significantly, with higher variance in the former, showing that shaded systems are more heterogeneous. Long et al. (2015) studying the effect of shade tree in robusta coffee production in Vietnam, observed that there were no differences in the number of and fruit set between shaded and unshaded coffee sites.

In respect to the $\mathrm{TPP}_{\text {benefited, the results were }}$ very similar to the TPP, where, the genotypes $03 \mathrm{~V}$ and $12 \mathrm{~V}$ presented significantly higher $\mathrm{TPP}_{\text {benefited }}$ when grown under FS and the genotype 06V in the LS, but that not was not significantly difference of FS and MS (Figure 5). The variables TPP and $\mathrm{TPP}_{\text {benefited }}$ generate a variable crucial in studies of grain yield, the relation TPP/TPPbenefited. This information is essential, because if the relation is high a great quantity of cherry fruits is necessary to produces one unity of benefited grain, that means more production cost. To the FS, LS, MS, and HS

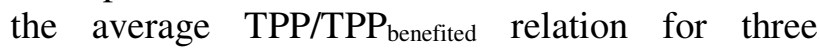
genotypes was: $4.18 / 1.0 ; 3.91 / 1.0 ; 3.45 / 1.0$ and 4.27/1.0. It means that even that in the FS occurs highest production (i.e., $03 \mathrm{~V}$ and $12 \mathrm{~V}$ ) the $\mathrm{TPP}_{\text {benefited }}$ can be lower than other conditions, because of the high relation (TPP/TPP benefited). .

The genotype $03 \mathrm{~V}$ presented an increase of production in the FS, but no variation in the LS, MS, and HS, except in the season 2016/17 to HS, where it showed an increase of yield (Figure 6). The genotype 06V has been showing that it a genotype responsive to shade, their variation annual was negative in the FS, while in the shade conditions were almost always to positively, except to season $2016 / 17$ to the LS and HS. The genotype 12V was similar the $03 \mathrm{~V}$, being more responsive the full sunlight condition, where had the highest production, independently of season (Figure 6). 

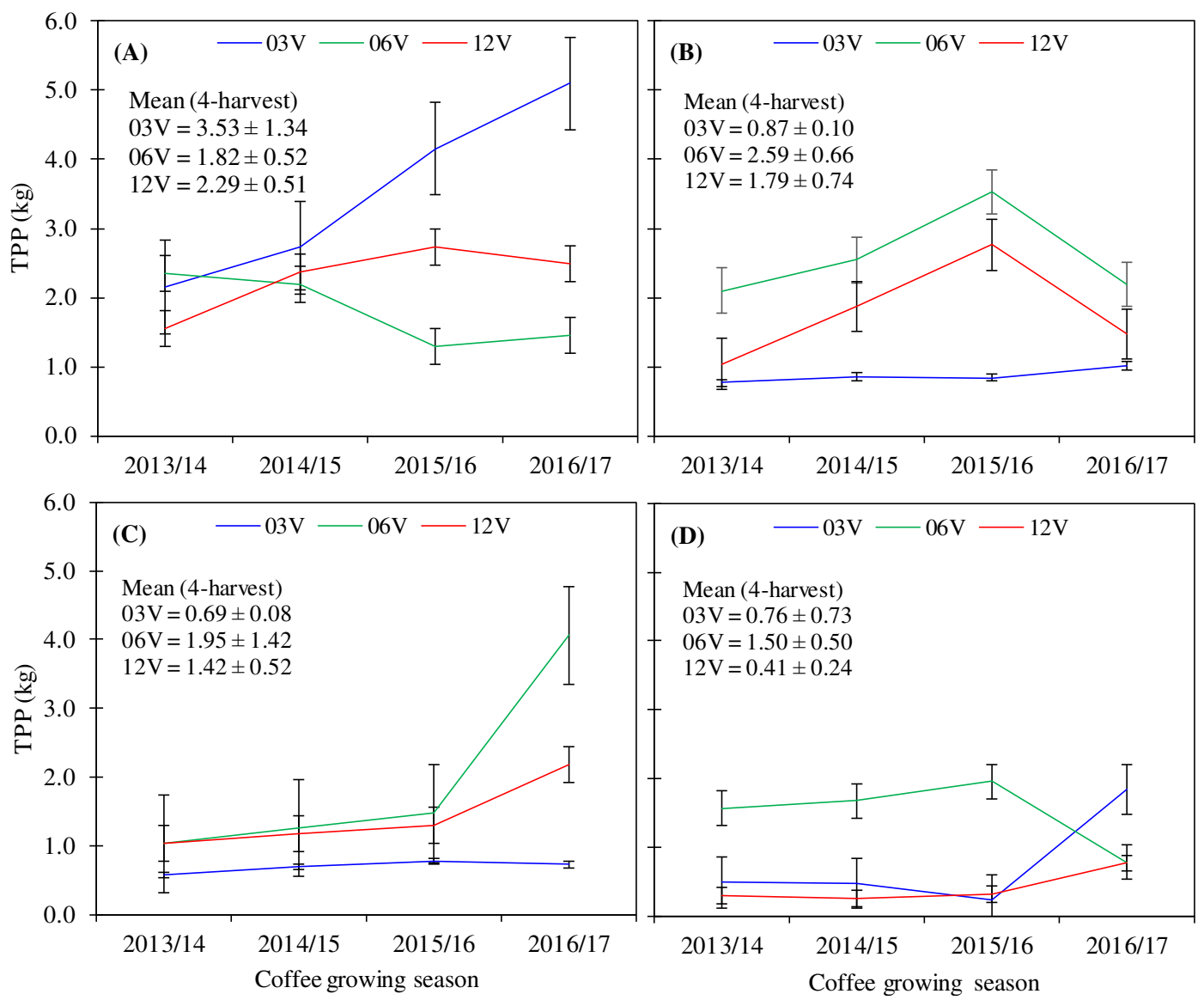

Figure 6. Annual variation of total fruit production per plant (TPP) with standard error for different Coffea canephora genotypes $(03 \mathrm{~V}, 06 \mathrm{~V}$ and $12 \mathrm{~V})$ grown under varying four shade level [full sunlight (A), low shade (B), moderate shade (C), and high shade (D)].

These variations can be related to production bienniality and with the climatic variations occurred in the Espírito Santo state, principally in the season 2015/16 and 2016/17. In 2014, the Espírito Santo state presented your bigger historic production with a production of 9.95 million of bags $(60 \mathrm{~kg})$, but this great value can't be maintained, justly by drought, associated to highs temperatures and excess of solar radiation. These problems could be mitigated by shading because it's considered a system with greater production stability than full sun system (ALVES et al., 2016).

With the results of our study, we can explain why many researches show an increase of yield in shade conditions and others a decrease. This large variation of results is a function of the plant material and the level of shade experienced by Robusta coffee clones, so, research with a lot of combinations is essential to finding the best association and help to break the paradigm existing in Brazil of that the shading in coffee robusta is synonymous of less yield. In Arabica coffee exist a lot of studies about the performance of genotypes in shaded systems, but in Robusta coffee the works are scarce, almost none, principally involving clonal variations.

\section{CONCLUSIONS}

The success of Robusta coffee shaded plantations depends of the correct choice of the shading responsive genotype and the best shade intensity for it. This was demonstrated by genotype $06 \mathrm{~V}$, that had the best performance of grain production under low shade and moderate shade conditions than in full sun, during the four harvests analysed.

The low, moderate, and high shade levels negatively affected the yield of coffee genotypes $03 \mathrm{~V}$ and $12 \mathrm{~V}$, showing be don't shade responsive genotypes.

Coffee plants in growth under shading had has a larger value for leaf area, orthotropic branch internode length and plagiotropic branch internode length. In general terms, the vegetative growth was positively influenced by shade level increase.

This work brings new results, useful to breeding programs and management of germplasm 
Vegetative growth...

of cafe Robusta, directing in the development of new studies with this objective.

\section{ACKNOWLEDGEMENTS}

This study was financed in part by the Coordenação de Aperfeiçoamento de Pessoal de
VENANCIO, L. P. et al.

Nível Superior - Brasil (CAPES) - Finance Code 001, by Conselho Nacional de Desenvolvimento Científico e Tecnológico - Brasil (CNPq), and by Fundação de Amparo à Pesquisa e Inovação do Espírito Santo - Brasil (FAPES).

RESUMO: O cultivo em sistemas sombreados é uma das estratégias adotadas para mitigar os impactos da mudança climática sobre os cafeeiros. No entanto, existem poucos estudos sobre o efeito do sombreamento no crescimento e produção de clones de café robusta (Coffea canephora). Além disso, existe um paradigma no Brasil de que o sombreamento nesta espécies é sinônimo de menor rendimento. Assim, o objetivo do presente trabalho foi avaliar se os genótipos de $C$. canephora submetidos ao sombreamento aumentam sua produtividade e crescimento vegetativo em condições de campo. O estudo foi realizado entre setembro de 2013 e julho de 2017 (quatro safras) em Alegre, Espírito Santo, Brasil. Três genótipos da cultivar Conilon Vitória - Incaper 8142 foram avaliados $(03 \mathrm{~V}, 06 \mathrm{~V}$ e $12 \mathrm{~V})$ e quatro níveis de sombreamento: pleno sol (testemunha) e baixo, moderado e alto nível de sombreamento, com 34, 48 e $68 \%$ de capacidade real de sombreamento, respectivamente, obtidos com o uso de telas de poliolefinas de cor preta; plantas cultivadas em pleno sol foram apenas cercadas. Os níveis de sombreamento testados afetaram a taxa de crescimento e produtividade das plantas de café Robusta $\mathrm{O}$ sombreamento provocou maior expansão foliar em relação ao pleno sol, bem como maior estiolação dos ramos plagiotrópicos e ortotrópicos. Os baixos, moderados e altos níveis de sombreamento afetaram negativamente a produção dos genótipos $03 \mathrm{~V}$ e $12 \mathrm{~V}$. O sombreamento pode melhorar o rendimento do café Robusta, neste caso, do genótipo 06V da cultivar Conilon Vitória - Incaper 8142. O sucesso das plantações cafeeiras sombreadas depende da escolha dos genótipos responsivos à sombra e do nível apropriado de sombreamento.

PALAVRAS-CHAVE: Coffea canephora. Intensidade de luz. Café sombreado. Produtividade.

\section{REFERENCES}

ALVARES, C. A.; STAPE, J. L.; SENTELHAS, P. C.; DE MORAES GONÇALVES, J. L.; SPAROVEK, G. Köppen's climate classification map for Brazil. Meteorologische Zeitschrift, v. 22, n. 6, p. 711-728, 2013. https://doi.org/10.1127/0941-2948/2013/0507

ALVES, V.; GOULART, F. F.; JACOBSON, T. K. B.; FILHO, R. J. de M.; RIBAS, C. E. D. C. Shade's Benefit: Coffee Production under Shade and Full Sun. Journal of Agricultural Science, v. 8, n. 11, p. 11-19, 2016. https://doi.org/10.5539/jas.v8n11p11

ANIM-KWAPONG, G. J.; ANIM-KWAPONG, E.; OPPONG, F. K. Evaluation of some robusta coffee (Coffea canephora pierre ex a. Froehner) clones for optimal density planting in Ghana. African Journal of Agricultural Research, v. 5, n. 1, p. 84-89, 2010.

ARAÚJO, A. V.; PARTELLI, F. L.; OLIOSI, G.; MACEDO PEZZOPANE, J. R. Microclimate, development and productivity of robusta coffee shaded by rubber trees and at full sun. Revista Ciência Agronômica, v. 47, n. 4, p. 700-709, 2016. https://doi.org/10.5935/1806-6690.20160084

BEENHOUWER, M.; AERTS, R.; HONNAY, O. A global meta-analysis of the biodiversity and ecosystem service benefits of coffee and cacao agroforestry. Agriculture, Ecosystems \& Environment, v. 175, p. 1-7, 2013. https://doi.org/10.1016/j.agee.2013.05.003

BERLYN, G. P.; CHO, J. Light, moisture, and nutrient use by plants. In: ASHTON, M. S.; MONTAGNINI, F. (Ed.). The Silvicultural Basis for Agroforestry Systems. Boca Raton: CRC Press, 2000, p. 9-39. 
CAMPANHA, M. M.; SANTOS, R. H. S.; DE FREITAS, G. B.; MARTINEZ, H. E. P.; GARCIA, S. L. R.; FINGER, F. L. Growth and yield of coffee plants in agroforestry and monoculture systems in Minas Gerais, Brazil. Agroforestry Systems, v. 63, n. 1, p. 75-82, 2004.

https://doi.org/10.1023/B:AGFO.0000049435.22512.2d

CHARBONNIER, F.; ROUPSARD, O.; LE MAIRE, G.; GUILLEMOT, J.; CASANOVES, F.; LACOINTE, A.; VAAST, P.; ALLINNE, C.; AUDEBERT, L.; CAMBOU, A.; CLÉMENT-VIDAL, A.; DEFRENET, E.; DUURSMA, R. A.; JARRI, L.; JOURDAN, C.; KHAC, E.; LEANDRO, P.; MEDLYN, B. E.; SAINTANDRÉ, L.; THALER, P.; VAN DEN MEERSCHE, K.; BARQUERO AGUILAR, A.; LEHNER, P.; DREYER, E. Increased light-use efficiency sustains net primary productivity of shaded coffee plants in agroforestry system. Plant Cell and Environment, v. 40, n. 8, p. 1592-1608, 2017.

https://doi.org/10.1111/pce.12964

CONAB - Companhia Nacional de Abastecimento. Acompanhamento da safra brasileira de café, v.5, safra 2018, primeiro levantamento, janeiro 2018. 2018. Disponível em: https://www.conab.gov.br/infoagro/safras/cafe/boletim-da-safra-de-cafe. Acesso em: 17 jun. 2018.

CONAB - Companhia Nacional de Abastecimento. Café Conilon - Brasil: série histórica de produtividade, safras 2008 a 2017. 2017. Disponível em: https://portaldeinformacoes.conab.gov.br/index.php/safras/cafeserie-historica. Acesso em: 17 jun. 2018.

COVRE, A. M.; PARTELLI, F. L.; BONOMO, R.; BRAUN, H.; RONCHI, C. P. Vegetative growth of Conilon coffee plants under two water conditions in the Atlantic region of Bahia State, Brazil. Acta Scientiarum. Agronomy, v. 38, n. 4, p. 535-545, 2016. https://doi.org/10.4025/actasciagron.v38i4.30627

DaMATTA, F. M.; ÁVILA, R. T.; CARDOSO, A. A.; MARTINS, S. C. V.; RAMANHO, J. C. Physiological and agronomic performance of the coffee crop in the context of climate change and global warming: a review. Journal of Agricultural and Food Chemistry, v. 66, n. 21, p. 5264-5274, 2018. https://doi.org/10.1021/acs.jafc.7b04537

DaMATTA, F.; RODRÍGUEZ, N. Sustainable production of coffee in agroforestry systems in the Neotropics: an agronomic and ecophysiological approach. Agronomía Colombiana, v. 25, n. 1, p. 113-123, 2007.

DaMATTA, FM. Ecophysiological constraints on the production of shaded and unshaded coffee: a review. Field Crops Research, v. 86, n. 2-3, p. 99-114, 2004. https://doi.org/10.1016/j.fcr.2003.09.001

HAGGAR, J.; BARRIOS, M.; BOLAÑOS, M.; MERLO, M.; MORAGA, P.; MUNGUIA, R.; PONCE, a.; ROMERO, S.; SOTO, G.; STAVER, C.; DE VIRGINIO, E. M. F. Coffee agroecosystem performance under full sun, shade, conventional and organic management regimes in Central America. Agroforestry Systems, v. 82, n. 3, p. 285-301, 2011. https://doi.org/10.1007/s10457-011-9392-5

JARAMILLO-BOTERO, C.; SANTOS, R. H. S.; MARTINEZ, H. E. P.; CECON, P. R.; FARDIN, M. P. Production and vegetative growth of coffee trees under fertilization and shade levels. Scientia Agricola, v. 67, n. 6, p. 639-645, 2010. https://doi.org/10.1590/S0103-90162010000600004

LEMOINE, R.; CAMERA, S. La; ATANASSOVA, R.; DÉDALDÉCHAMP, F.; ALLARIO, T.; POURTAU, N.; BONNEMAIN, J.-L.; LALOI, M.; COUTOS-THÉVENOT, P.; MAUROUSSET, L.; FAUCHER, M.; GIROUSSE, C.; LEMONNIER, P.; PARRILLA, J.; DURAND, M. Source-to-sink transport of sugar and regulation by environmental factors. Frontiers in Plant Science, v. 4, n. 7, p. 1-21, 2013.

https://doi.org/10.3389/fpls.2013.00272

LIN, B. B. Agroforestry management as an adaptive strategy against potential microclimate extremes in coffee agriculture. Agricultural and Forest Meteorology, v. 144, n. 1-2, p. 85-94, 2007.

https://doi.org/10.1016/j.agrformet.2006.12.009 
LIU, Y.; DAWSON, W.; PRATI, D.; HAEUSER, E.; FENG, Y.; VAN KLEUNEN, M. Does greater specific leaf area plasticity help plants to maintain a high performance when shaded? Annals of Botany, v. 118, n. 7, p. 1329-1336, 2016. https://doi.org/10.1093/aob/mcw180

LONG, N. V.; NGOC, N. Q.; DUNG, N. N.; KRISTIANSEN, P. The effects of shade tree types on light variation and robusta coffee production in Vietnam. Engineering, v. 7, n. 11, p. 742-753, 2015. https://doi.org/http://dx.doi.org/10.4236/eng.2015.711015

MORAIS, H.; CARAMORI, P. H.; RIBEIRO, A. M. De A.; GOMES, J. C.; KOGUISHI, M. S. Microclimatic characterization and productivity of coffee plants grown under shade of pigeon pea in Southern Brazil.

Pesquisa Agropecuária Brasileira, v. 41, n. 1, p. 763-770, 2006.

https://doi.org/http://dx.doi.org/10.1590/S0100-204X2006000500007

MORAIS, H.; MEDRI, M. E.; MARUR, C. J.; CARAMORI, P. H.; DE ARRUDA RIBEIRO, A. M.; GOMES, J. C. Modifications on leaf anatomy of Coffea arabica caused by shade of pigeonpea (Cajanus cajan). Brazilian Archives of Biology and Technology, v. 47, n. 6, p. 863-871, 2004. https://doi.org/10.1590/S151689132004000600005

OLIOSI, G.; GILES, J. A. D.; RODRIGUES, W. P.; RAMALHO, J. C.; PARTELLI, F. L. Microclimate and development of Coffea canephora cv . Conilon under different shading levels promoted by Australian cedar (Toona ciliata M. Roem . var . Australis ). Australian Journal of Crop Science, v. 10, n. 4, p. 528-538, 2016. https://doi.org/10.21475/ajcs.2016.10.04.p7295x

PARTELLI, F. L.; ARAÚJO, A. V.; VIEIRA, H. D.; DIAS, J. R. M.; DE MENEZES, L. F. T.; RAMALHO, J. C. Microclimate and development of "Conilon" coffee intercropped with rubber trees. Pesquisa Agropecuária Brasileira, v. 49, n. 11, p. 872-881, 2014. https://doi.org/10.1590/S0100-204X2014001100006

PARTELLI, F. L.; VIEIRA, H. D.; SILVA, M. G.; RAMALHO, J. C. Seasonal vegetative growth of different age branches of conilon coffee tree. Semina: Ciências Agrárias, v. 31, p. 619-626, 2010.

PEZZOPANE, J. R. M.; SOUZA, P. S. De; ROLIM, G. D. S.; GALLO, P. B. Microclimate in coffee plantation grown under grevillea trees shading. Acta Scientiarum. Agronomy, v. 33, n. 2, p. 201-206, 2011. https://doi.org/10.4025/actasciagron.v33i2.7065

RODRÍGUEZ-LÓPEZ, N. F.; CAVATTE, P. C.; SILVA, P. E. M.; MARTINS, S. C. V.; MORAIS, L. E.; MEDINA, E. F.; DaMATTA, F. M. Physiological and biochemical abilities of robusta coffee leaves for acclimation to cope with temporal changes in light availability. Physiologia Plantarum, v. 149, p. 45-55, 2013. https://doi.org/10.1111/ppl.12010

RODRÍGUEZ-LÓPEZ, N. F.; MARTINS, S. C. V.; CAVATTE, P. C.; SILVA, P. E. M.; Morais, L. E.; PEREIRA, L. F.; REIS, J. V.; ÁVILA, R. T.; GODOY, A. G; LAVINSKI, A. O; DaMATTA, F. M. Morphological and physiological acclimations of coffee seedlings to growth over a range of fixed or changing light supplies. Environmental and Experimental Botany, v. 102, p. 1-10, 2014. https://doi.org/10.1016/j.envexpbot.2014.01.008

RONCHI, C. P.; DE ALMEIDA, W. L.; SOUZA, D. S.; DE SOUSA, J. M.; DE MOURA GUERRA, A. M. N.; PIMENTA, P. H. C. Morphophysiological plasticity of plagiotropic branches in response to change in the coffee plant spacing within rows. Semina: Ciências Agrárias, v. 37, n. 6, p. 3819-3834, 2016. https://doi.org/10.5433/1679-0359.2016v37n6p3819

SILES, P.; HARMAND, J.-M.; VAAST, P. Effects of Inga densiflora on the microclimate of coffee (Coffea arabica L.) and overall biomass under optimal growing conditions in Costa Rica. Agroforestry Systems, v. 78, p. 269-286, 2010. https://doi.org/10.1007/s10457-009-9241-y 
SMITH, H. Light quality, photoperception, and plant strategy. Annual review of plant physiology, v. 33, n. 1, p. 481-518, 1982. https://doi.org/10.1146/annurev.pp.33.060182.002405

STEIMAN, S.; IDOL, T.; BITTENBENDER, H. C.; GAUTZ, L. Shade coffee in Hawai ' $\mathrm{i}$ - Exploring some aspects of quality, growth, yield, and nutrition. Scientia Horticulturae, v. 128, n. 2, p. 152-158, 2011. https://doi.org/10.1016/j.scienta.2011.01.011

VALENCIA, V.; GARCÍA-BARRIOS, L.; WEST, P.; STERLING, E. J.; NAEEM, S. The role of coffee agroforestry in the conservation of tree diversity and community composition of native forests in a Biosphere Reserve. Agriculture, Ecosystems \& Environment, v. 189, p. 154-163, 2014.

https://doi.org/10.1016/j.agee.2014.03.024

WU, Y.; GONG, W.; YANG, W. Shade Inhibits Leaf Size by Controlling Cell Proliferation and Enlargement in Soybean. Scientific Reports, v. 7, n. 1, p. 1-10, 2017. https://doi.org/10.1038/s41598-017-10026-5 